\title{
Estimating the timing of maximum pollen release from jack pine (Pinus banksiana Lamb.) in northern Ontario
}

\author{
by F. Di-Giovanni ${ }^{1}$, P. G. Kevan ${ }^{2}$ and G.-É. Caron ${ }^{3}$
}

\begin{abstract}
A practical heat sum method was validated for estimating the date of maximal pollen release of jack pine (Pinus banksiana Lamb.) in northern Ontario. The base temperature and start date that minimized differences between estimated and observed maximum pollen release dates were sought. Heat sums were calculated for all data sets $(n=26)$ for a range of base temperatures $\left(1\right.$ to $20^{\circ} \mathrm{C}$ ) and start dates (January 1 to maximum pollen release). The best combination was a start date at Julian day 107 and base temperature at $4^{\circ} \mathrm{C}$. The heat sum to maximum pollen release was 288.58 degree days and the average difference between estimated and observed was 2.75 days. Recommendations for operational testing are made.
\end{abstract}

Key words: heat sum, phenology, Pinus banksiana Lamb., temperature, pollen, dehiscence, contamination, seed orchard
Une méthode pratique basée sur les degrés-jours cumulés a été validée dans le but d'estimer la date de relâchement maximal de pollen chez le pin gris (Pinus banksiana Lamb.) du nord de l'Ontario. La température de référence et la date de début qui minimisent les différences entre les dates estimées et observées de relâchement maximal de pollen ont été recherchées. Les degrés-jours cumulés ont été calculés pour toutes les séries de données $(n=26)$ pour un ensemble de température de référence $\left(1\right.$ à $\left.20^{\circ} \mathrm{C}\right)$ et de dates de début (du $1^{\mathrm{er}}$ janvier au relâchement maximal de pollen). La meilleure combinaison débutait au $104^{\mathrm{e}}$ jour du calendrier romain avec une température de référence de $4^{\circ} \mathrm{C}$. Le nombre de degrésjours cumulés pour atteindre le relâchement maximal de pollen était de 288.58 et la différence moyenne entre le nombre de jours estimé et observé était de 2.75 jours. Des recommandations pour la mise en application sont incluses dans l'article.

Mots clés: cumul des degrés-jours, phénologie, Pinus banksiana Lamb., température, pollen, déhiscence, contamination, verger à graines

\section{Introduction}

Pollen contamination can be reduced in seed orchards (Denison and Franklin 1975; Squillace and Long 1981) by use of such timing-dependent methods as water-spray cooling (Fashler and Devitt 1980), controlled pollination (Bramlett and O'Gwynn 1981) and supplemental mass pollination (Blush et al. 1993; Bridgewater et al. 1993), but it is important to apply these methods just before pollination occurs. Therefore, to increase the chances of success, it is essential that the date of pollination be known in advance. The timing of pollen release for conifers can be predicted by calculating heat sum requirements (Boyer 1973).

Heat sums are the sums of temperatures during a time interval (days or hours) within which the average temperature is used to calculate degree-days or degree-hours, respectively. The temperatures are usually accumulated above a base temperature and after a start date. These base temperatures or start dates may be chosen following some biological reasoning. For example, Owens and Molder (1977), investigating the timing of cone-bud differentiation, found that the heat sum method could be used to predict the date if the start date used coincided with the end of vegetative bud dormancy. In most cases,

\footnotetext{
${ }^{1}$ Climate Processes and Earth Observation Research Division, Climate Research Branch, Environment Canada, C.A.R.E., RR\#1, Egbert, Canada LOL 1NO. (Present address: 76 Ptarmigan Drive, Guelph, Ontario, Canada N1C 1B6.)

${ }^{2}$ Department of Environmental Biology, University of Guelph, Guelph, Ontario Canada N1G 2W1.

${ }^{3}$ École de sciences forestières, C.U.S.L.M., Université de Moncton, Edmundston, New Brunswick, Canada E3V 2S8.
}

however, start dates and base temperatures are calculated empirically using data gathered throughout a number of years and/or at a number of sites (Yang et al. 1995).

Generally, heat sums required for a given stage of plant growth to be reached vary from year-to-year (Boyer 1973) possibly influenced by other factors such as differences in insolation, altitude (Ebell and Schmidt 1964), different plant responses to environmental changes at different stages of their lives and non-linear growth-temperature relationships near temperature extremes (Wang 1960). However, Fowler (1965) reported that in 1961 there was a difference of no more than two days in onset of pollen shedding among red pines (Pinus resinosa Ait.) in a planting representing nine climatic regions. The foregoing suggests heat sums should be used with caution and knowledge of their applicability.

If the heat sum required for a plant to reach a given stage varies, then its usefulness depends on the degree of variability. Attempts have been made to increase the precision of heat sums in forecasting by using various base temperatures and start dates until a less variable year-to-year heat sum was found. Lindsey and Newman (1956) and Boyer (1973) used standard deviations and coefficients of variation of the mean heat sum for various threshold temperatures and start dates to find the combination giving the least variable heat sum. Castonguay et al. (1984) found that the coefficient of variation and standard error of prediction were equally effective in calculating optimal base temperatures and start dates. Hickin and Vittum (1976) and Andersen (1991) used standard deviation of differences between observed and estimated dates as the statistic to test model predictability. Despite the accurate predictions in the above, the statistical methods measure the precision of the heat sum model rather than its accuracy (Hunter and 
Lechowicz 1992) and have inherent statistical problems (Boyer 1973). However, Hunter and Lechowicz (1992) used Hickin and Vittum's (1976) method to predict bud burst in northern hardwoods and also measured accuracy by calculating the chi-squared value between estimated and observed bud burst dates. They found that accurate heat sum models were also precise. Further, Thomson and Moncrieff (1982) estimated bud burst in Douglas-fir by degree-day accumulation and minimizing the average difference between estimated and observed budburst. Their method required minimal statistical assumptions.

For this work, data from a wide geographical region were obtained rather than just a single site and from trees covering ranges of ages and site factors so as to incorporate representation of variability for jack pine. Thomson and Moncrieff's (1982) method was applied to pollen release, to find the combination of start date and base temperature that minimized yearly differences in heat sum requirements. This method required a minimum of statistical assumptions and made it suitably robust for operational use. This method was combined with the considerations of Hunter and Lechowicz (1992) regarding accuracy and precision. Finally, by careful analysis of the assumptions implicit in the heat sum method, operational considerations were developed to estimate the timing of conifer pollen release. As an example the procedure was applied to jack pine (Pinus banksiana Lamb.) in northern and eastern Ontario.

\section{Materials and Methods}

\section{(i) Data Sets}

All available data sets (temperatures and dates of maximum pollen release) for jack pine in Ontario (three sites) were gathered. Site one: Island Lake Tree Improvement Area (ILTIA; $47^{\circ}, 40.3$ N $, 83^{\circ} 37^{\prime} \mathrm{W}, 451 \mathrm{~m}$ a.s.l.) $1989-94$; Site two: 20 pollination dates for jack pine recorded at Petawawa National Forestry Institute (PNFI; 455'N, 77²6' W, 183 m a.s.l.) 1952-1994; and Site three: four pollination dates at Ranmore seed orchard complex $\left(48^{\circ} 24^{\prime} 40^{\prime \prime} \mathrm{N}, 80^{\circ} 17^{\prime} 24^{\prime \prime} \mathrm{W}, 305 \mathrm{~m}\right.$ a.s.1.) 1989-1994 (Fig. 1). Most conifer pollen is released in short, well defined periods of 2-3 days (e.g. Sarvas 1968; Blush et al. 1993). Peak days were used to define the time of pollen release because the start date of pollen capture is sampler dependent (Hirst and Stedman 1961).

At ILTIA, various samplers were used: from 1989 to 1991 sticky slides (Greenwood and Rucker 1985), from 1992 to 1993 Model 95 rotorod samplers (Sampling Technologies, Los Altos Hills, CA) and in 1994 estimated by visual observation of male strobili. At Ranmore sticky slide samplers were used, but estimated by observation in 1994. All the PNFI dates were estimated from pollination records (actual day pollinated) from breeding work conducted at PNFI. Because pollination is usually completed in such a short time, any differences due to measurement technique are thought negligible.

Daily maximum and minimum temperatures for ILTIA were gathered from a nearby meteorological station (Environment Canada, Chapleau Airport, approximately $40 \mathrm{~km}$ to the NW). For Ranmore, daily maximum and minimum temperatures from the nearest meteorological station (Kirkland Lake Airport approximately $40 \mathrm{~km}$ to the SW) were collected. For PNFI, daily maximum and minimum temperatures were obtained from the Environment Canada meteorological station at PNFI (Fig.

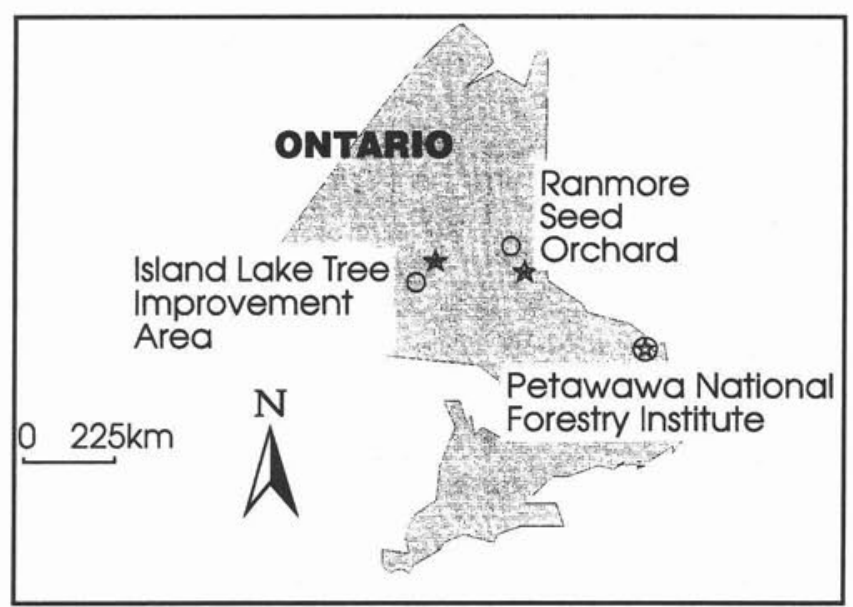

Fig. 1. Locations of the seed orchards $(O)$ and meteorological stations (자) used in this study.

1). All pollination observations at PNFI were within $40 \mathrm{~km}$ of the meteorological station. Missing data (only discrete, individual days were missing) were replaced by estimates using linear interpolation. Daily heat sums were calculated using the sine curve method (Allen 1976).

\section{(ii) Analysis}

Heat sums were calculated using Thomson and Moncrieff's (1982) method for all data sets for a range of base temperatures and start dates. Data from ILTIA in 1989 and 1994, Ranmore in 1994 and PNFI in 1994 were not used in the development of the heat sum estimate; they were left as separate data sets with which to test any resultant estimate. Thus, a total of 26 data sets were used. Start dates ranged from 1 January to the day of maximum pollen release in one day increments and base temperatures ranged from 1 to $20^{\circ} \mathrm{C}$ in $1^{\circ} \mathrm{C}$ increments. The average resultant heat sums for each combination of start date and base temperature using all data sets were calculated. These averaged heat sums were then used to calculate an estimated day of pollen release for each data set by calculating the day on which the average heat sum was achieved based on the daily temperatures recorded in the data set and the start date and base temperature associated with the average heat sum. The average difference (where, for example, differences of +2 and -2 days would average to zero days difference) between all observations and the single estimation of pollination date for each combination of start date and base temperature was then calculated. The combination of threshold temperature, start date and associated average heat sum giving the least difference over all data sets was adopted as the best "model". We also measured accuracy by calculating the chi-squared value between estimated and observed dates (Gibbons 1985; Hunter and Lechowicz 1992) and these were examined to find combinations with greatest accuracy (lowest $\chi^{2}$ value).

No upper threshold, or developmental maximum, was used for temperature. That is, we assumed temperatures never reached those levels for pollen cone maturation to cease for jack pine in northern Ontario. Even if this assumption is not met, we assume that this assumption only produced negligible errors in our northern region (Higley et al. 1986). 
Table 1. Combinations of start date and base temperature resulting in a minimum difference between estimated and observed pollination dates. These four combinations are tested using independent data to find the best predictor

\begin{tabular}{|c|c|c|c|c|c|c|c|c|c|}
\hline \multirow[b]{2}{*}{$\begin{array}{l}\text { Start date } \\
\text { (Julian } \\
\text { day) }\end{array}$} & \multirow[b]{2}{*}{$\begin{array}{c}\text { Base } \\
\text { temperature } \\
\left({ }^{\circ} \mathrm{C}\right) \\
\end{array}$} & \multirow[b]{2}{*}{$\begin{array}{c}\text { Average heat } \\
\text { sum }\left({ }^{\circ} \mathrm{C} \text { days }\right)\end{array}$} & \multirow[b]{2}{*}{$\begin{array}{c}\begin{array}{c}\text { Range of } \\
\text { differences } \\
\text { (days) }\end{array} \\
\end{array}$} & \multirow[b]{2}{*}{$\begin{array}{c}\chi^{2} \\
\text { (days) }\end{array}$} & \multicolumn{4}{|c|}{ Estimated day by model } & \multirow[b]{2}{*}{$\begin{array}{c}\text { Average } \\
\text { difference } \\
\text { of } \\
\text { estimated } \\
\text { day }\end{array}$} \\
\hline & & & & & $\begin{array}{l}\text { ILTIA } \\
1989 \\
\text { (observed } \\
=166 \text { ) }\end{array}$ & $\begin{array}{l}\text { ILTIA 1994 } \\
\text { (observed } \\
=166 \text { ) }\end{array}$ & $\begin{array}{c}\text { RANMORE } \\
1994 \\
\text { (observed = } \\
164)\end{array}$ & $\begin{array}{l}\text { PNFI 1994 } \\
\text { (observed } \\
=150 \text { ) }\end{array}$ & \\
\hline $107^{1}$ & 4 & 288.58 & 10 & 1.00 & 161 & 158 & 158 & 153 & 2.75 \\
\hline 122 & 15 & 38.94 & 26 & 5.84 & 161 & 151 & 155 & 150 & 6.00 \\
\hline 140 & 12 & 33.03 & 21 & 4.76 & 150 & 145 & 150 & 145 & 12.75 \\
\hline 141 & 16 & 13.54 & 27 & 6.58 & 161 & 143 & 150 & 144 & 10.75 \\
\hline
\end{tabular}

${ }^{1}$ Combination that had the lowest variation in differences, i.e., lowest $\chi^{2}$ value. Average difference was -0.58 days.

\section{Results}

The range of maximal pollen release data was 21 May to 13 June. The mean day of maximum pollen release was Julian day 151 (equivalent to 31 May, non-leap year).

Analysis of the minimum average difference for the estimated dates yielded a number of combinations (Table 1) of start date and base temperature producing the same, minimum, difference of 0.0 days. The $\chi^{2}$ values pointed to one combination with maximum accuracy. The four combinations to be tested are given (Table 1).

Pollen release dates were estimated in the four separate data sets to decide on the most useful model. The model with the greatest accuracy also gave the lowest average difference when tested separately (Table 1). Thus, the combination of start date $=$ Julian day 107 , base temperature $=4^{\circ} \mathrm{C}$ and heat sum $=288.58$ is proposed as the "best" prediction model to estimate the maximum dehiscence for jack pine in northern and eastern Ontario. This model produced an average discrepancy between observed and estimated maximum release of 2.75 days.

\section{Discussion}

The heat sum method is basically a mathematical construct which may be more or less related to physiology (Thomson and Moncrieff 1982; Higley et al. 1986; Luomajoki 1995). The start date and base temperature are not based on any biological factors [as were those of Owens and Molder (1977)] but note that the base temperature for jack pine pollen release is close to the $4.4^{\circ} \mathrm{C}$ value that Boyer (1973) found for longleaf pine in the southern United States.

It is difficult to compare the predictive ability of our estimate to those of other workers because of different methodologies and because others have not tested resultant models with separate data sets. Also, there are very few studies dealing with conifer pollination specifically. Nonetheless the average difference of our estimate is comparable to that reported by other authors: Hickin and Vittum (1976) estimated lilac leafing with a standard error of \pm 6.0 days; Boyer (1973) found an average deviation of 1.6 days for an area encompassing North Carolina and Alabama (roughly comparable in geographical distance to that between the data sets used in this study); Hunter and Lechowicz (1992) found a standard error of estimation of between 2.1-7.0 days; Thomson and Moncrieff (1982) estimated average bud burst date to \pm 1 day in $80 \%$ of the years covered by their data; Castonguay et al. (1984) produced an error of estimation of between 3.08 and 4.88 days, and Andersen (1991) was able to predict pollen shed of Alnus, Ulmus and Betula to within 3-5 days of the observed dates in Denmark.

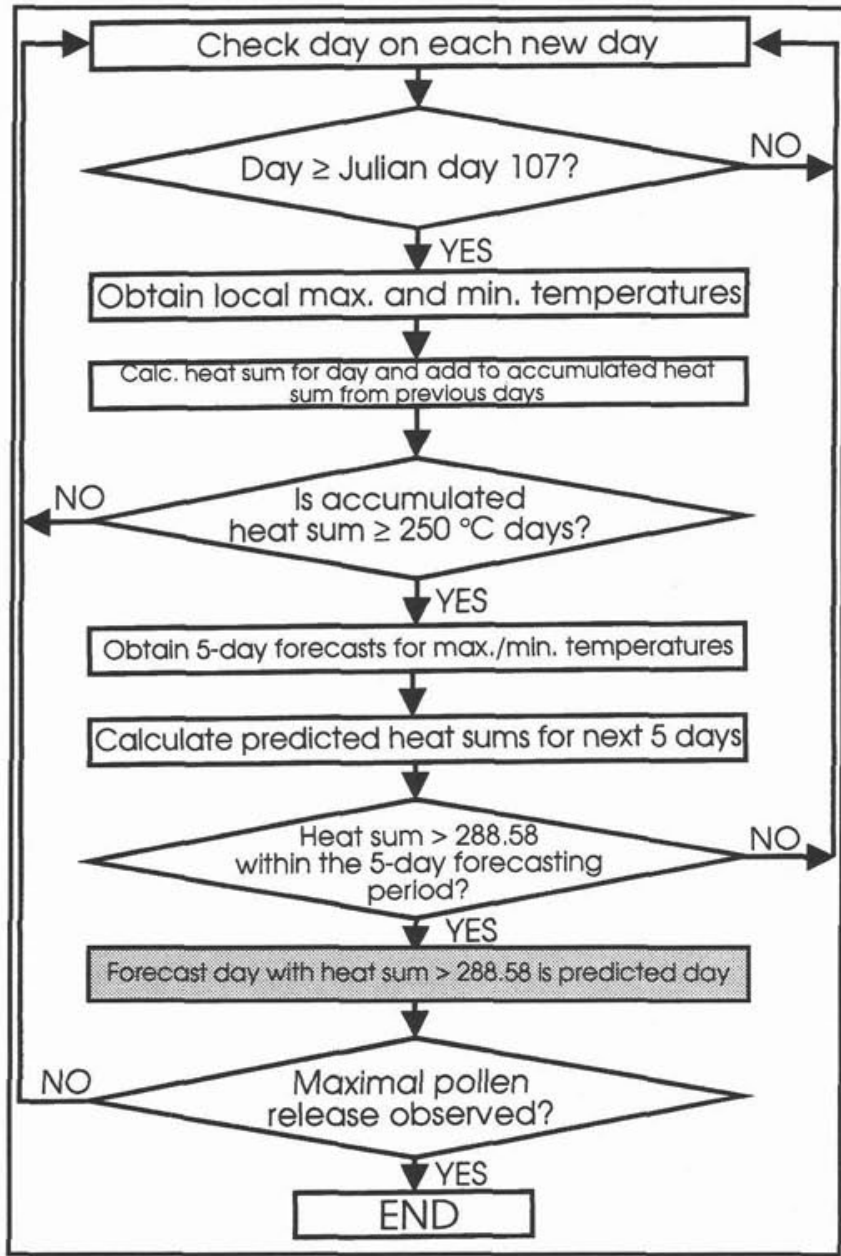

Fig. 2. Flow-chart indicating the procedure to predict the maximal pollen release date for jack pine in northern and eastern Ontario. This could be easily converted into a computer program.

The model accuracy of 2.75 days found in this study is commensurate with the time period of maximum pollen release (of the order of 2-3 days). However, this does not indicate the operational accuracy of the model. Operational testing, to our knowledge, has not been done with previous models. It is our hope that co-operative work with potential users will be initiated in order to test the present model.

This method has been tested using past data, but to use the method in an operational environment and test its predictive ability the following is suggested (Fig. 2). The seed orchard manager can contact the local weather office once a week dur- 
ing the early spring after the proposed start date given here, obtain daily maximum and minimum temperatures, and use those figures to calculate heat sum. Contact should be frequent (every day) as pollination time approaches. Very close to pollination time, the seed orchard manager should use the fiveday weather forecasts (the maximum, accurate forecast period that can be made) to predict pollination time. However, weather forecasts themselves are often wrong. For example, average differences of $2-3^{\circ} \mathrm{C}$ were found between predicted and observed maximum and minimum temperatures during the summer of 1994 for all of Canada for five-day forecast periods (Verret 1994).

The work could be extended to investigate synchrony between the seed orchard and the natural stand or to aid reproductive synchronization among clones or families in seed orchards (Blush et al. 1993). Unfortunately, there are few data available with which to develop such a system. Further, the model can aid logistics in research into phenology and also as an aid to pollen collection (Beers et al. 1981; Jett et al. 1993), or to assess the effects of moving seed orchards to warmer climates (Enescu 1987; Schmidtling 1987). Nonetheless, in its present form, the method could provide a powerful tool to seed orchard managers and could be used in other administrative areas or with other commercial trees species whose pollen release is well predicted by heat sums.

\section{Acknowledgements}

This work was supported by the Ministry of Natural Resources (Northern Region), the Ontario Tree Improvement Board, NSERC funding to the second author (A8098), Canadian Climate Centre and Climate Research Branch (Environment Canada), Forestry Canada/NSERC (696-006/91) and OMNR-ORRRG (010-91). We acknowledge the Petawawa National Forestry Institute and the Ontario Tree Improvement Board for access to pollination records. The first author was supported by an NSERC Visiting Fellowship. Invaluable assistance is acknowledged from: T. Elders, V. Wearn, D. Joyce, D.C. MacIver, D.W. McNichol and B. Smith. Appreciation is extended to A.J. Thomson, M.J. Lechowicz, P.A. Scott and W.H. Fogel and our anonymous reviewers for comments on this paper.

\section{References}

Allen, J.C. 1976. A modified sine wave method for calculating degree days. Environ. Entomol. 5: 388-396.

Andersen, T.B. 1991. A model to predict the beginning of the pollen season. Grana 30: 269-275.

Beers, W.L. Jr., J. Bivens and J.E. Mocha. 1981. Pollen collection. pp. 30-31 In: Pollen management handbook, E.C. Franklin (ed.). Agric. Handb. 587. US Department of Agriculture, Forest Service, Washington, DC.

Blush, T.D., D.L. Bramlett and Y.A. El-Kassaby. 1993. Reproductive phenology of seed orchards. pp. 15-23 In: D.L. Bramlett, G.R. Askew, T.D. Blush, F.E. Bridgewater and J.B. Jett (eds.). Advances in pollen management. Agric. Handb. 698. US Department of Agriculture, Forest Service, Washington, DC.

Boyer, W.D. 1973. Air temperature, heat sums, and pollen shedding phenology of longleaf pine. Ecology 54: 420-426.

Bramlett, D.L. and C.H. O'Gywnn. 1981. Controlled pollination. pp. 44-51 In: Pollen management handbook. E.C. Franklin (ed.). Agric. Handb. 587. US Department of Agriculture, Forest Service, Washington, DC.

Bridgewater, F.E., T.D. Blush and N.C. Wheeler. 1993. Supplemental mass pollination. pp. 69-77 In: D.L. Bramlett, G.R. Askew, T.D. Blush, F.E. Bridgewater and J.B. Jett (eds.) Advances in pollen management.
Agric. Handb. 698. US Department of Agriculture, Forest Service, Washington, DC.

Castonguay, Y., J. Boisvert and P.A. Dubé. 1984. Comparison de techniques statistiques utilisées dans l'élaboration de modèles prévisionnels phénoclimatiques. Agric. For. Meteorol. 31: 273-288.

Denison, S.I. and E.C. Franklin. 1975. Pollen management. pp. 92-100 In: R. Faulkner (ed.) Seed orchards. UK For. Comm. Bull. No. 54. HMSO, London.

Ebell, L. F. and R. L. Schmidt. 1964. Meteorological factors affecting conifer pollen dispersal on Vancouver Island. Dept. For. Can. Forest Research Branch. Publ. No. 1036.

Enescu, V. 1987. Climate and the choice of seed orchard sites. For. Ecol. Manage. 19: 257-265.

Fashler, A.M.K. and W.J.B. Devitt. 1980. A practical solution to Douglas-fir seed orchard pollen contamination. For. Chron. 56: 237-241.

Fowler, D.P. 1965. Effects of inbreeding in red pine, Pinus resinosa Ait. III. Factors affecting natural selfing. Silvae Genet. 14: 37-46. Gibbons, J.D. 1985. Nonparamteric methods for quantitative analysis. 2nd edn. American Sciences Press Inc., Columbus, $\mathrm{OH}$.

Greenwood, M. and T. Rucker. 1985. Estimating pollen contamination in loblolly pine seed orchards by pollen trapping. pp. 179-186 In: Proc. 18th South. For. Tree Improv. Conf., Long Beach, Mississippi, USA, 21-23 May 1985.

Hickin, R.P. and M.T. Vittum. 1976. The importance of soil and air temperature in spring phenoclimatic modelling. Int. J. Biometeor. 20: 200-206.

Higley, L.G., L.P. Pedigo and K.R. Ostile. 1986. DEGDAY: A program for calculating degree-days, and assumptions behind the degree-day approach. Environ. Entomol. 15: 999-1016.

Hirst, J.M. and O.J. Stedman. 1961. The epidemiology of apple scab (Venturia inaequalis (Cke.) Wint.). Ann. appl. Biol. 49: 290-305.

Hunter, A.F. and M.J. Lechowicz. 1992. Predicting the timing of bud burst in temperate trees. J. Appl. Ecol. 29: 597-604.

Jett, J.B., D.L. Bramlett, J.E. Webber and U. Eriksson. 1993. Pollen collection, storage, and testing. pp. 41-46 In: D.L. Bramlett, G.R. Askew, T.D. Blush, F.E. Bridgewater and J.B. Jett. eds. Advances in pollen management. Agric. Handb. 698. US Department of Agriculture, Forest Service, Washington, DC.

Lindsey, A.A. and J.E. Newman. 1956. Use of official weather data in spring time - temperature analysis of an Indiana phenological record. Ecology 37: 812-823.

Luomajoki, A.J. 1995. Phenological measurements of microsporogenesis in trees. Tree Physiology 15: 499-505.

Owens, J.N. and M. Molder. 1977. Bud development in Picea glauca. II. Cone differentiation and early development. Can. J. Bot. 55: 2746-2760.

Sarvas, R. 1968. Investigations on the flowering and seed crop of Picea abies. Communicationes Instituti Forestalis Fenniae.

Schmidtling, R.C. 1987. Locating pine seed orchards in warmer climates: benefits and risks. For. Ecol. Manage. 19: 273-283.

Squillace, A.E. and E.M. Long. 1981. Proportion of pollen from nonorchard sources. pp. 15-19 In: E.C. Franklin (ed.) Pollen management handbook. US Department of Agriculture, For. Serv., Agric. Handb. No. 587.

Thomson, A.J. and S.M. Moncrieff. 1982. Prediction of bud burst in Douglas-fir by degree-day accumulation. Can. J. For. Res. 12: 448-452. Verret, R. 1994. Verifications of objective forecasts of weather elements, September 1 to November 30, 1993. Canadian Meteorological Centre Review 1(4): 27-35.

Wang, J.Y. 1960. A critique of the heat unit approach to plant response studies. Ecology 41(4): 785-790.

Yang, S., J. Logan and D.L. Coffey. 1995. Mathematical formulae for calculating the base temperature for growing degree days. Agric. For. Meteorol. 74: 61-74. 